\title{
Efektifitas Aloe vera terhadap Luka Bakar
}

\author{
Ashilah Mumtaz Hakim \\ Pendidikan Dokter, Fakultas Kedokteran, Universitas Lampung \\ * e-mail: ashilahculla@gmail.com
}

\begin{abstract}
Abstrak
Obat-obatan herbal adalah bentuk pengobatan yang didasarkan pada penggunaan tanaman dengan potensi bioaktivitas yang tinggi. Terapi ini telah digunakan sepanjang sejarah untuk pengobatan berbagai penyakit. Terapi telah diturunkan dari generasi ke generasi untuk menjadi pengetahuan umum yang berhubungan dengan budaya, kesehatan, dan peningkatan kualitas hidup terhadap penyakit tertentu. Aloe vera atau Aloe vera adalah tanaman mirip kaktus yang, dalam beberapa penelitian pada hewan coba dan manusia telah terbukti memiliki manfaat. Digunakan untuk mempercepat penyembuhan luka, melalui proses biologis kompleks yang bertanggung jawab untuk pemulihan jaringan dan telah digunakan sejak zaman kuno. Bukti ilmiah tentang manfaat Aloe vera akan sangat bermanfaat, karena penggunaannya dapat meningkatkan kepatuhan terhadap pengobatan terhadap pasien karena luka yang cepat membaik dan juga dapat menurunkan biaya. Aloe vera telah digunakan secara eksternal untuk mengobati berbagai kondisi kulit seperti luka bakar dan eksim. Diduga getah dari Aloe vera meringankan rasa sakit dan mengurangi peradangan. Memiliki sifat antiseptik dan antibiotic. Studi klinis berdasarkan bukti ilmiah diperlukan untuk mendapatkan pemahaman yang lebih baik tentang Aloe vera, senyawanya dan indikasi terapeutik
\end{abstract}

Kata Kunci: Aloe vera, Luka, Luka bakar

\section{Effectiveness of Aloe vera on Burns}

\begin{abstract}
Herbal medicines are a form of treatment that is based on the use of plants with high bioactivity potential. These therapies have been used throughout history for the treatment of various diseases. Therapy has been passed down from generation to generation to become general knowledge related to culture, health, and improvement of quality of life for certain diseases. Aloe vera or Aloe vera is a cactus-like plant which, in several studies in experimental animals and humans, has been shown to have benefits. Used to accelerate wound healing, through complex biological processes that are responsible for tissue recovery and have been used since ancient times. Scientific evidence about the benefits of Aloe vera will be very useful, because its use can improve adherence to treatment of patients because the wound is rapidly improving and can also reduce costs. Aloe vera has been used externally to treat various skin conditions such as burns and eczema. Allegedly the sap from Aloe vera alleviates pain and reduces inflammation. Has antiseptic and antibiotic properties. Clinical studies based on scientific evidence are needed to get a better understanding of Aloe vera, its compounds and therapeutic indications)
\end{abstract}

Keywords: Aloe vera, Wound, Burn 


\section{PENDAHULUAN}

Kulit adalah salah satu organ terbesar dalam tubuh yang melakukan banyak fungsi vital termasuk homeostasis cairan, termoregulasi, fungsi imunologis, neurosensori dan metabolisme (Schommer and Gallo 2013). Kulit juga memberikan perlindungan utama terhadap infeksi dengan bertindak sebagai penghalang fisik. Ketika penghalang ini rusak, patogen memiliki rute langsung untuk menyusup ke tubuh, yang berpotensi mengakibatkan infeksi. Urutan peristiwa yang memperbaiki kerusakan dikategorikan menjadi tiga fase yang tumpang tindih: peradangan, proliferasi dan remodeling jaringan (Lai-Cheong and McGrath, 2017).

Proses penyembuhan yang normal dapat terhambat pada setiap langkah oleh berbagai faktor yang dapat berkontribusi pada gangguan penyembuhan. Gangguan penyembuhan luka mungkin merupakan konsekuensi dari keadaan patologis yang terkait dengan diabetes, gangguan kekebalan tubuh, iskemia, stasis vena dan luka-luka seperti luka bakar, luka yang disebabkan karena terlalu dingin dan luka tembak. Langkah terakhir dari fase proliferatif adalah epitelisasi, melibatkan migrasi, proliferasi dan diferensiasi sel-sel epitel dari tepi luka untuk melapisi kembali dengan kerusakan jaringan Pada luka bakar, epitelisasi ditunda sampai lapisan jaringan granulasi terbentuk untuk memungkinkan migrasi sel-sel epitel (Wang et al, 2018).

Aloe vera memiliki efek antiinflamasi yang berpotensi signifikan, oleh karena itu dapat digunakan dalam mengobati: gingivitis (Dhingra, 2014), dan luka bakar tingkat pertama hingga kedua (Dat et al, 2014). Aplikasi Aloe vera (AV) secara topikal telah terbukti memiliki efek yang menjanjikan pada proses penyembuhan luka.

Penelitian ini merupakan studi literature review, di mana peneliti mencari, menggabungkan inti sari serta menganalisis fakta dari beberapa sumber ilmiah yang akurat dan valid, yang mendukung dan menjadi bukti. Studi literatur menyajikan ulang materi yang diterbitkan sebelumnya, dan melaporkan fakta atau analisis baru. Tinjauan literatur memberikan ringkasan berupa publikasi terbaik dan paling relevan. kemudian membandingkan hasil yang disajikan dalam makalah

\section{PEMBAHASAN}

\section{Aloe vera}

Tanaman semi-tropis, Aloe vera, memiliki sejarah panjang dan diberi peringkat tinggi sebagai tanaman herbal serba guna. Daun Aloe vera yang tebal, 
meruncing, tumbuh dari tangkai pendek dekat permukaan tanah. Aloe vera bukan termasuk dalam kaktus, tetapi anggota keluarga pohon lily, yang dikenal sebagai Aloe barbadensis. Aloe terkait dengan anggota lain dari keluarga Lily seperti, bawang putih dan keluarga lobak. Hubungan Aloe vera dengan keluarga bunga bakung terlihat dari bunga kuning berbentuk tabung yang diproduksi setiap tahun di musim semi yang menyerupai bunga bakung Paskah (Manvitha and Bidya, 2014).

Aloe berasal dari Afrika dan sekarang dibudidayakan di daerah beriklim hangat di
Asia, Eropa dan Amerika. Saat ini, penggunaan Aloe vera telah mendapatkan popularitas karena gerakan herbal yang diprakarsai oleh naturopaths, guru yoga, promotor pengobatan alternatif dan penyembuh holistik. Laporan analisis pasar baru-baru ini menunjukkan bahwa Pasar Aloe vera di Amerika terfokus pada makanan fungsional, minuman dan suplemen untuk bahan baku kosmetik serta untuk menyediakan energi dan nutrisi tambahan untuk menangani masalah kesehatan seperti hiperkolesterolemia dan diabetes (Maan et al, 2018).

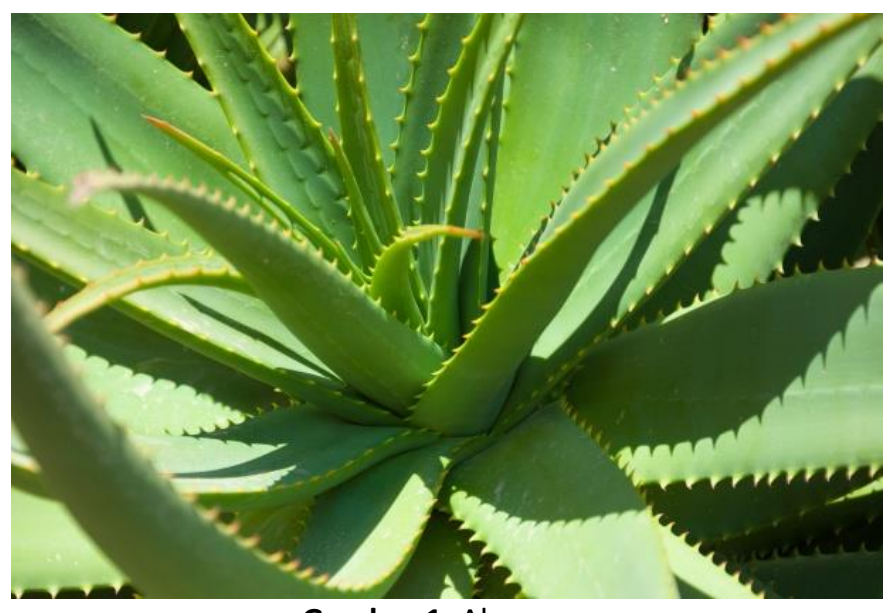

Gambar 1. Aloe vera

\section{Kandungan Aloe vera}

Saat ini, industri Aloe vera sedang berkembang dalam banyak produk seperti gel, jus dan formulasi lain untuk tujuan kesehatan, pengobatan dan kosmetik. Namun, industri Aloe vera yang berkembang pesat sangat membutuhkan protokol pengujian yang dapat diandalkan untuk menilai kualitas dan kuantitas bahan kimia bioaktif yang ada dalam produk akhir. Klaim produk harus diuji dengan uji klinis intensif, diverifikasi dan disertifikasi oleh otoritas pemerintah untuk membangun kepercayaan konsumen dan keamanan produk Aloe vera (Chandegara and Varshney, 2013). 
Gel daun Aloe vera mengandung sekitar 98\% air. Kandungan padatan total gel Aloe vera adalah $0,66 \%$ dan padatan terlarut $0,56 \%$ dengan beberapa fluktuasi musiman. Pada bahan kering, gel Aloe vera terdiri dari polisakarida (55\%), gula (17\%), mineral (16\%), protein (7\%), lipid (4\%) dan senyawa fenolik (1\%). Gel Aloe vera mengandung banyak vitamin termasuk vitamin antioksidan penting, $\mathrm{C}$ dan $\mathrm{E}$. Vitamin B1 (tiamin), niasin, Vitamin B2 (riboflavin), kolin dan asam folat juga ada. Terdapat juga vitamin B12 (cyanocobalamin) dalam jumlah kecil yang biasanya tersedia dalam sumber hewani. Karbohidrat berasal dari lapisan lendir tanaman di bawah kulit, mengelilingi parenkim bagian dalam atau gel. Mereka terdiri dari mono dan polisakarida
(Bharadwaj et al, 2018). Yang paling penting adalah polisakarida rantai panjang, yang terdiri dari glukosa dan mannose, yang dikenal sebagai glukomanan $[\beta$ linked acetylated mannan]. Xylose, rhamnose, galactose, dan arabinose juga ada dalam jumlah kecil bersama dengan lupeol (a triterpenoid), kolesterol, campesterol dan $\beta$-sitosterol. Studi struktural pada polisakarida gel Aloe vera telah menunjukkan bahwa dari setidaknya empat glukomanan terasetilasi parsial berbeda, menjadi polimer linier tanpa percabangan dan memiliki hubungan glikosidik dengan glukosa dan mannose dalam perbandingan 1: 2: 8. Viskositas gel berkurang pada hidrolisis gula-gula ini (Pandey and Singh, 2016).

Tabel 1. Komponen kimia dan efek Aloe vera terhadap kesehatan (Pandey and Singh 2016)

\begin{tabular}{|c|c|}
\hline Komponen Kimia & Efek terhadap Kesehatan \\
\hline $\begin{array}{l}\text { Acemannan } \\
\text { Alprogen } \\
\text { C-glycosyl chromone } \\
\text { Bradykinase } \\
\text { Magnesium lactate } \\
\text { Salicylic acid }\end{array}$ & $\begin{array}{c}\text { Mempercepat penyembuhan luka; memodulasi } \\
\text { sistem kekebalan, efek Antineoplastik dan } \\
\text { antivirus. } \\
\text { Anti-allergic } \\
\text { Anti-inflammatory } \\
\text { Anti-inflammatory } \\
\text { Anti-inflammatory } \\
\text { Analgesic, anti-inflammatory }\end{array}$ \\
\hline $\begin{array}{l}\text { Luka Bakar } \\
\text { Luka bakar berada di peringkat } \\
\text { keempat dalam semua cedera dan } \\
\text { mempengaruhi tidak hanya kulit tetapi } \\
\text { seluruh tubuh sesuai dengan kedalaman } \\
\text { dan ekstensinya (Busuioc et al, 2013). }\end{array}$ & $\begin{array}{l}\text { Meskipun ada kemajuan dalam } \\
\text { pengobatan, insiden jaringan parut tetap } \\
\text { tinggi (Penn et al, 2012) dan kematian lebih } \\
\text { dari } 300.000 \text { orang setiap tahun di seluruh } \\
\text { dunia (Peck, 2011). Penyembuhan luka } \\
\text { bakar pada dasarnya tergantung pada }\end{array}$ \\
\hline
\end{tabular}


angiogenesis yang merupakan jalur utama dalam pembentukan jaringan granulasi (Reinke and Sorg, 2012). Pericytes adalah sel yang berasal sumsum tulang yang tertanam dalam membran basal kapiler (Ribatti et al, 2011). Selama proses angiogenesis, ada interaksi yang sangat kuat antara sel endotel dan pericytes. Selain itu, pericytes memainkan peran kunci tidak hanya dalam proliferasi dan migrasi endotelium dan tetapi juga dalam stabilisasi (Busuioc et al, 2011). Selain itu, sel-sel inflamasi yang ditransmigrasi berinteraksi dengan membran basal endotel untuk memasuki lokasi luka.

Berdasarkan kedalaman, luka bakar dibagi menjadi 4 jenis: superfisial (derajat 1), ketebalan parsial dalam (derajat 2), ketebalan penuh (derajat 3), dan derajat 4 (Giretzlehner et al, 2013). Luka bakar biasanya dapat dicegah, dan perawatan yang berbeda diterapkan berdasarkan tingkat keparahan luka bakar. Kadangkadang, salep, krim, pembalut biologis dan nonbiologis, serta antibiotik direkomendasikan untuk luka bakar tingkat 2,3 , dan 4. Beberapa penyalahgunaan obat seperti dosis yang tidak tepat dapat meningkatkan risiko resistensi antibiotik dan infeksi jamur, bahkan memperlambat penyembuhan luka dan meningkatkan kedalaman luka bakar (Avni et al, 2010).
Pada luka bakar derajat Pertama Epidermis utuh, ada eritema, misalnya disebabkan oleh terbakar sinar matahari. Pada luka bakar derajat kedua integritas epidermal rusak. Jika cedera terbatas pada lapisan atas dermis, digolongkan pada luka bakar superfisial tingkat kedua. Namun, keterlibatan lapisan yang lebih dalam (reticular) menyebabkan luka bakar derajat kedua yang dalam. Sementara luka bakar superfisial biasanya jauh lebih menyakitkan, dibandingkan luka bakar tingkat dalam yaitu dengan sedikit rasa sakit dan perasaan tumpul dalam luka bakar. Tingkat ketiga semua lapisan dermis terlibat. Kulit keras, gelap, kering, tidak nyeri, trombosis di dalam pembuluh, dan ada eschar bakar yang khas. Derajat Keempat semua lapisan kulit, jaringan lemak subkutan dan jaringan yang lebih dalam (otot, tendon) terlibat, dan terdapat karbonisasi (Yasti, 2015).

Penelitian pada hewan coba dan manusia sudah banyak dilaporkan, seperti penelitian yang dilakukan oleh Hosseinimehr et al (2010) untuk mengevaluasi kemanjuran krim Aloe vera dalam pengobatan luka bakar termal dan untuk membandingkan hasilnya dengan perak sulfadiazine pada tikus. Hewan dibagi menjadi empat kelompok. Hewan coba diberikan krim topikal (Aloe vera bubuk gel $0,5 \%$ dan perak sulfadiazin) pada 
24 jam dari luka bakar yang disebabkan oleh air panas. Ukuran luka dan histopatologi sampel kulit ditentukan pada kelompok hewan yang diberi terapi topikal. Ukuran luka secara signifikan mengecil pada kelompok yang diberikan Aloe vera dibandingkan dengan kelompok lain. Hasil penelitian ini menunjukkan krim Aloe vera secara signifikan meningkatkan reepitelisasi pada luka bakar dibandingkan dengan perak sulfadiazine (Hosseinimehr et al, 2010).

Presentasi kasus oleh Avijgan et al pada seorang wanita korban luka bakar berusia 17 tahun dirujuk ke Departemen Penyakit Menular. Sebelumnya, telah mengalami 30\% - 40\% luka bakar kulit akibat kebakaran tingkat dua di tungkai atas, leher, wajah, telinga, kulit kepala, kelopak mata, dan dada anterior 40 hari sebelum dia masuk ke rumah sakit. pasien telah dirawat di unit perawatan luka bakar lain dan prosedur cangkok kulit pada dada anterior dan telah dilakukan oleh seorang ahli bedah plastik dengan mengambil kulit sehat dari paha, tetapi cangkok mengalami penolakan setelah 5 hari (Gambar 2). Pasien dirawat karena cedera kulit kronis yang tidak sembuh dan kegagalan cangkok kulit. Luka pada kulit memiliki sekresi serosa yang dibalut oleh Vaseline gas. Selama pemeriksaan fisik pasien mengalami takipnea, dispnea, demam, tanda vital tidak stabil dengan tingkat Saturasi $\mathrm{O}_{2}$ yang berfluktuasi, stridor ringan, dan bilateral crackle sounds pada kedua paru-paru. Sehubungan dengan pengamatan luka bakar di daerah presternal, telinga, dan pre-umbilicus berkerak. Lesi kulit lainnya terasa hangat, sedikit lunak, dan eritematik dengan sekresi serosa 


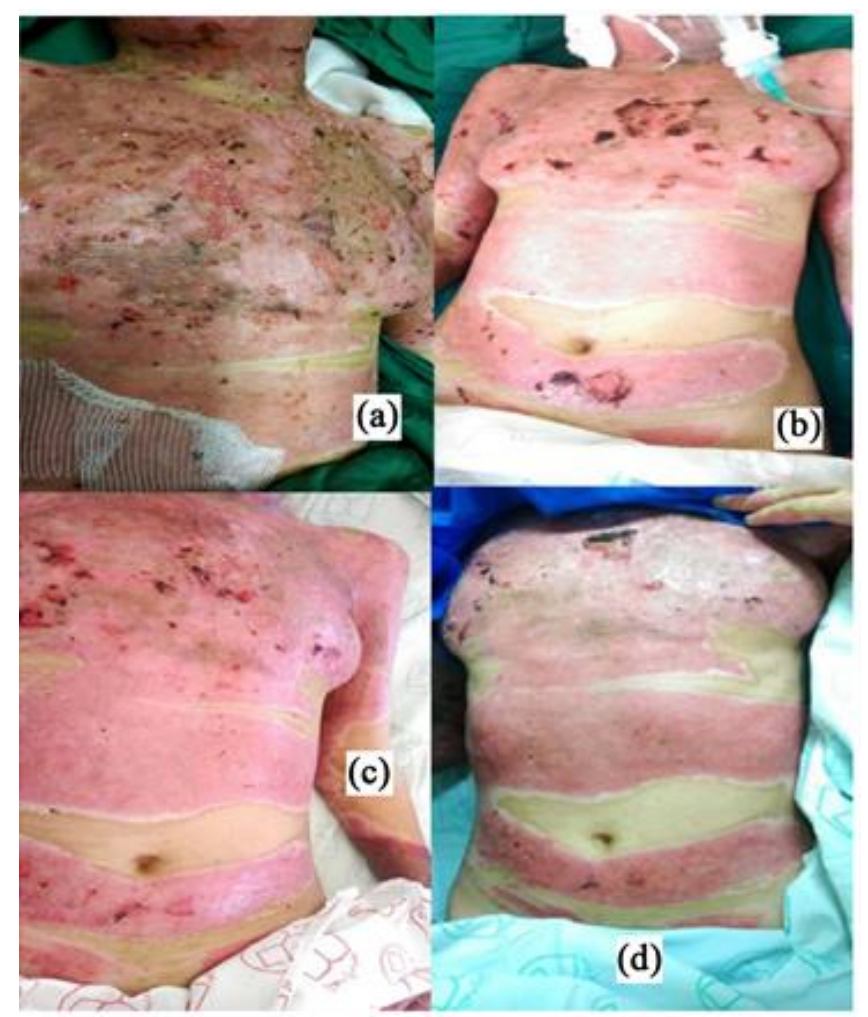

Gambar 2. (a) Gejala luka bakar kulit kronis dan penolakan cangkok kulit di bagian thorax pasien pada saat masuk rumah sakit; (b) 13 Hari setelah aplikasi Aloe vera; (c) Pembentukan jaringan granulasi pada hari ke-18 pengobatan; (d) Penyembuhan luka secara menyeluruh dan dimulainya epitelisasi 21 hari setelah pengobatan Aloe vera Gel.

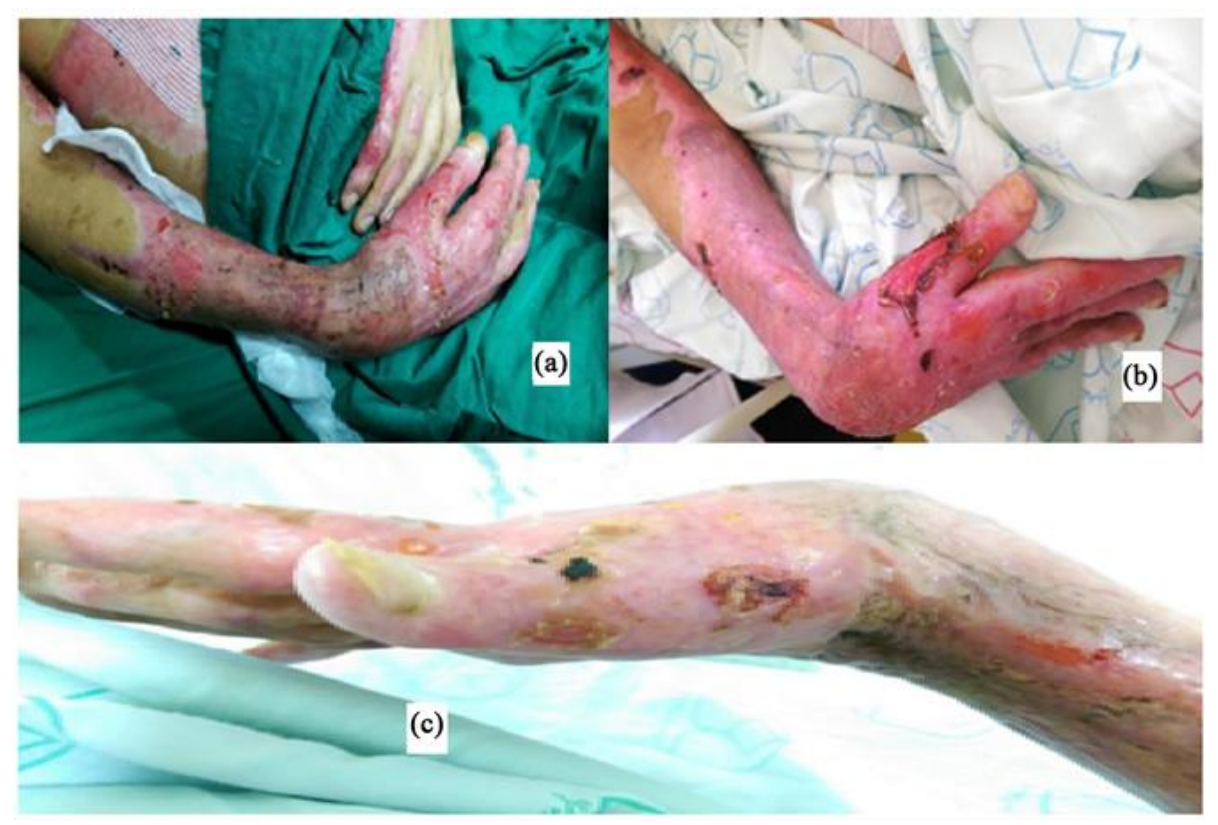

Gambar 3. (a) Cedera kulit saat awal masuk; (b) lesi setelah 14 hari pengobatan; (c) Pembentukan jaringan granulasi dan epitelisasi lesi pada hari ke-21. 
Mengenai luka pada kulit pasien, Gel Aloe vera dioleskan setiap 12 jam sebagai pengganti balutan Vaseline Gas. Untuk mempersiapkan Gel Aloe vera, lendir Aloe vera dan gel pelumas (Gel pelumas yang diproduksi oleh Iran, pabrik instrumen perawatan, merek Salem) dicampur dengan rasio lima banding satu. Pembalutan luka dengan gel lidah buaya dilakukan pada seluruh area luka bakar selama 21 hari secara terus menerus. Proses penyembuhan kulit dimulai dengan pembentukan jaringan granulasi dan epitelisasi pada luka (Gambar 2 dan Gambar 3). Namun, kulit baru terasa keras dan tegang di area cedera seperti leher dan siku setelah 21 hari. Tapi, tidak ada tandatanda infeksi kulit yang terdeteksi selama perawatan. Selain itu, pasien melaporkan tidak ada efek samping topikal dari Aloe vera Gel seperti reaksi alergi dan gatalgatal. Meskipun sekresi serosa luka berhenti, fibrosis kulit telah menyebabkan peningkatan ketegangan kulit dan striktur sendi di tungkai atas meskipun fisioterapi yang tepat dimulai pada saat pasien masuk ICU setelah 40 hari pengobatan Aloe vera Gel. Operasi plastik tambahan dilakukan untuk melepaskan ketegangan kulit dan meringankan berbagai gerakan sendi tungkai atas (Avijgan et al, 2017)

Penelitian yang langsung dilakukan terhadap 32 pasien oleh Shahzad dan
Ahmed yang dioleskan dengan gel Aloe vera dan 32 pasien lainnya mengenakan krim perak sulfadiazine $1 \%$, setiap hari. Parameter luka pada hari 1, 7, dan 15 dipelajari menggunakan alat penilaian luka Bates-Jensen. Dengan membandingkan peningkatan rata-rata pada kedua kelompok pada awal dan pada hari ke 15 , perbedaan yang signifikan ditemukan antara kedua kelompok ( $\mathrm{P}<0,0001)$ dilaporkan bahwa luka sembuh lebih cepat dengan penggunaan gel Aloe vera daripada perak sulfadiazine (Shahzad and Ahmed, 2013).

Penyembuhan luka merupakan respons biologis yang esensial terhadap regenerasi jaringan ikat dan epitel yang rusak. Penerapan topical Aloe vera telah terbukti memiliki efek yang menjanjikan pada proses penyembuhan luka. Aloe vera mungkin memiliki kemanjuran yang lebih besar di atas krim perak sulfadiazin untuk mengobati luka bakar sesuai dengan penelitian yang bahwa Aloe vera menginduksi pematangan kolagen yang lebih cepat (Rahman et al, 2017)

Beberapa peneliti menghubungkan terapi Aloe vera dengan glukomanan, polisakarida yang kaya mannose dan peran giberelin yang merupakan hormon pertumbuhan, berinteraksi dengan reseptor pada fibroblas, sehingga merangsang aktivitas dan proliferasinya, 
yang pada gilirannya mempercepat sintesis kolagen setelah aplikasi topikal Aloe vera (Koga et al, 2018)

Studi lain menunjukkan bahwa Aloe vera menjadi penghambat kolagenase yang mungkin bertanggung jawab untuk kolagen yang lebih baik dalam kelompok yang diobati dengan Aloe vera (Hekmatpou et al, 2019). Sifat Aloe vera dan senyawanya, dapat digunakan untuk mempertahankan kelembaban dan integritas kulit, juga mencegah ulserasi pada kulit karena mengandung mucopolysaccharides, asam amino, seng, dan air. Dalam hal kualitas dan kecepatan penyembuhan luka, Aloe vera jauh lebih efektif dan lebih murah dibandingkan dengan perawatan alternatif yang tersedia saat ini( Mahor and Ali, 2016). Mengingat kecenderungan untuk mempromosikan obat tradisional serta efek samping Aloe vera yang jarang dilaporkan, penggunaan tanaman obat ini untuk meningkatkan penyembuhan luka dianjurkan sebagai pengobatan komplementer bersama metode lain.

\section{KESIMPULAN}

Bukti yang ada menunjukkan bahwa Aloe vera yang digunakan dalam berbagai bentuk sediaan mungkin efektif dalam mempercepat proses penyembuhan luka dan cenderung meningkatkan tingkat keberhasilan penyembuhan, dan laju epitelisasi pada luka bakar pertama dan kedua jika dibandingkan dengan perawatan konvensional. Penelitian yang dirancang lebih lanjut dengan rincian yang cukup dari isi produk Aloe vera harus dilakukan untuk menentukan efektivitas Aloe vera untuk penyembuhan luka bakar

\section{DAFTAR PUSTAKA}

Avijgan $M$, Alinaghian $M$, and Hafizi $M$, 2017. Aloe vera Gel as a Traditional and Complementary Method for Chronic Skin Burn: A Case Report. Advances in Infectious Diseases. 7(01).

Avni T, Levcovich A, Ad-EI DD, Leibovici L, and Paul M, 2010. Prophylactic Antibiotics for Burns Patients: Systematic Review and MetaAnalysis. BMJ (Online). 340: c241

Bharadwaj B, Priya VV, and Balakrishna RN, 2018. Aloe vera - A Review. Drug Invention Today. 10(4): 37043708.

Busuioc CJ, Mogoşanu GD, Popescu FC, Lascăr I, Pârvǎnescu H et al, 2013. Phases of the Cutaneous Angiogenesis Process in Experimental Third-Degree Skin Burns: Histological and Immunohistochemical Study. Romanian Journal of Morphology and Embryology. 54(1): 163-171. 
Chandegara VK and Varshney AK, 2013. Aloe vera $\mathrm{L}$. Processing and Products: A Review. Int. J. Med. Arom. Plants. 3: 492-506.

Dat $A D$, Poon F, Pham KBT, and Doust J, 2014. Aloe vera for Treating Acute and Chronic Wounds. Sao Paulo Medical Journal. 132(6): 382.

Dhingra K, 2014. Aloe vera Herbal Dentifrices for Plaque and Gingivitis Control: A Systematic Review. Oral Diseases. 20(3): 254267.

Giretzlehner $M$, Dirnberger J, Owen R, Haller HL, Lumenta DB, and Kamolz LP, 2013. The Determination of Total Burn Surface Area: How Much Difference? Burns. 39(6): 11071113.

Hekmatpou D, Mehrabi F, Rahzani K, and Aminiyan A, 2019. The Effect of Aloe vera Clinical Trials on Prevention and Healing of Skin Wound: A Systematic Review. Iranian Journal of Medical Sciences. 44(1): 1-9.

Hosseinimehr SJ, Khorasani G, Azadbakht M, Zamani P, Ghasemi $M$ et al, 2010. Effect of Aloe Cream versus Silver Sulfadiazine for Healing Burn Wounds in Rats. Acta Dermatovenerologica Croatica.
18(1): $2-7$.

Koga AY, Pereira AV, Lipinski LC, and Oliveira MRP, 2018. Evaluation of Wound Healing Effect of Alginate Films Containing Aloe vera (Aloe Barbadensis Miller) Gel. Journal of Biomaterials Applications. 35(5): e202000507.

Lai-Cheong JE and McGrath JA, 2017. Structure and Function of Skin, Hair and Nails. Medicine. 37(5): 223-226.

Maan AA, Nazir A, Khan MKI, Ahmad T, Zia $\mathrm{R}$ et al, 2018. The Therapeutic Properties and Applications of Aloe vera: A Review. Journal of Herbal Medicine. 12: 1-10.

Mahor G and Ali SA, 2016. Recent Update on the Medicinal Properties and Use of Aloe vera in the Treatment of Various Ailments. Bioscience Biotechnology Research Communications. 9(2): 273-288.

Manvitha K and Bidya B, 2014. Aloe vera: A Wonder Plant Its History, Cultivation and Medicinal Uses. Journal of Pharmacognosy and Phytochemistry. 2(5): 85-88.

Pandey A and Singh S, 2016. Aloe vera: A Systematic Review of Its Industrial and Ethno-Medicinal Efficacy. International Journal of Pharmaceutical Research and 
Allied Sciences. 5(1): 21-33.

Peck MD, 2011. Epidemiology of Burns throughout the World. Part I: Distribution and Risk Factors. Burns. 37(7): 1087-1100.

Penn JW, Grobbelaar AO, and Rolfe KJ, 2012. The Role of the TGF- $\beta$ Family in Wound Healing, Burns and Scarring: A Review. International Journal of Burns and Trauma. 2(1): 18-28.

Rahman S, Carter P, and Bhattarai N, 2017. Aloe vera for Tissue Engineering Applications. Journal of Functional Biomaterials. 8(1): 6 .

Reinke JM and Sorg H, 2012. Wound Repair and Regeneration. European Surgical Research. 49(1): 35-43.

Ribatti D, Nico B, and Crivellato E, 2011. The Role of Pericytes in Angiogenesis. International Journal of Developmental Biology. 55(3): 261-268.
Schommer NN, and Gallo RL, 2013. Structure and Function of the Human Skin Microbiome. Trends in Microbiology. 21(12): 660-668.

Shahzad MN, and Ahmed N, 2013. Effectiveness of Aloe vera Gel Compared with $1 \%$ Silver Sulphadiazine Cream as Burn Wound Dressing in Second Degree Burns. Journal of the Pakistan Medical Association. 63(2): 225230.

Wang $\mathrm{PH}$, Huang BS, Horng HC, Yeh CC, and Chen YJ, 2018. Wound Healing. Journal of the Chinese Medical Association. 81(2): 94101.

Yasti AC, Senel E, Saydam M, Ozok G, Coruh A et al, 2015. Guideline and Treatment Algorithm for Burn Injuries. Turkish Journal of Trauma and Emergency Surgery. 21(2): 79-89. 